\title{
Isolasi dan Identifikasi Bakteri Resisten Arsen pada Sedimen Tanah di Pesisir Pantai Ratatotok
}

\author{
${ }^{1}$ Muh. Irsan Hidayat \\ ${ }^{2}$ Aaltje Manampiring \\ ${ }^{2}$ Billy J. Kepel
}

\author{
${ }^{1}$ Program Studi Pendidikan Dokter Fakultas Kedokteran Universitas Sam Ratulangi Manado \\ ${ }^{2}$ Bagian Kimia Fakultas Kedokteran Universitas Sam Ratulangi Manado \\ Email: irsanh55@gmail.com
}

\begin{abstract}
Arsenic is classified chemically as a metalloid which has both properties of metal and nonmetal. Production and application of arsenic in industries such as mining is a source of enviromental pollution. Therefore, agents for remediation process are needed. Arsenic resistant bacteria become a target of many studies related to its utilization as bioremediation agent. This study was aimed to obtain arsenic resistant bacteria identificated from soil sediment in the coastal area of Ratatotok Beach. This was an explorative descriptive study. Samples were colonies of arsenic resistant bacteria found in the soil sediment of the coastal area of Ratatotok Beach. The results of arsenic-resistant test showed that there were arsenicresistant bacteria in every concentration. The morphological, physiological, and biochemical tests obtained four arsenic-resistant bacterial genus, namely Staphylococcus, Klebsiella, Hafnia, and Enterobacter. Conclusion: Four genera of arsenic-resistant bacteria identified in the sediment of the coastal area of Ratatotok Beach, as follows: Staphylococcus, Klebsiella, Hafnia, and Enterobacter.
\end{abstract}

Keywords: arsenic, sediment, arsenic resistant bacteria

\begin{abstract}
Abstrak. Arsenik diklasifikasikan secara kimia sebagai metaloid yaitu memiliki kedua sifat logam dan bukan logam. Produksi dan penggunaan arsen di dalam kegiatan industri seperti industri pertambangan, merupakan salah satu sumber pencemarannya di lingkungan. Arsen merupakan polutan bagi lingkungan sehingga diperlukan suatu agen untuk proses remediasi. Bakteri resisten arsen menjadi target dari banyak penelitian dalam rangka pemanfaatannya sebagai agen bioremediasi. Penelitian ini bertujuan untuk mengetahui jenis bakteri resisten arsen yang teridentifikasi pada sedimen tanah di pesisir pantai Ratatotok. Jenis penelitian yaitu dekriptif eksploratif. Sampel yang digunakan yaitu koloni bakteri resisten arsen yang terdapat dalam sedimen tanah pesisir pantai Ratatotok. Hasil uji resistensi arsen mendapatkan adanta bakteri resisten arsen pada setiap konsentrasi uji. Setelah dilakukan uji morfologi, fisiologi, dan biokomia didapatkan empat genus bakteri yang resisten terhadap arsen: Staphylococcus, Klebsiella, Hafnia, dan Enterobacter. Simpulan: Terdapat empat genus bakteri resisten arsen yang teridentifikasi dalam sedimen tanah pesisir pantai Ratatotok, yaitu Staphylococcus, Klebsiella, Hafnia, dan Enterobacter.
\end{abstract}

Keyword: arsen, sedimen tanah pesisir, bakteri resisten arsen

Arsenik diklasifikasikan secara kimia sebagai metaloid yaitu memiliki dua sifat: logam dan bukan logam. Secara umum senyawa arsenik anorganik dan organik berupa bubuk putih atau tidak berwarna yang tidak dapat menguap. Arsenik anorganik secara alami terdapat di tanah dan di berbagai jenis batuan, terutama dalam mineral dan bijih yang mengandung tembaga atau timah. ${ }^{1}$ 
Produksi dan penggunaan arsen di dalam kegiatan industri seperti pengolahan bijih logam, industri pestisida, industri pertambangan, industri pelapisan logam, dan proses penghilangan cat atau paint stripping merupakan salah satu sumber pencemarannya di lingkungan. Keterlibatan manusia dalam menyebabkan atau memperburuk polusi arsenik dapat ditelusuri penyebabnya pada kegiatan yang terkait dengan pertambangan. ${ }^{2,3}$

Studi oleh Blackwood dan Edinger ${ }^{4}$ pada tahun 2002 dan 2004 menunjukkan konsentrasi tinggi arsenik (590-660 ppm) pada sedimen laut dangkal dari Teluk Buyat dan Ratatotok. Selanjutnya, Edinger et al. $^{4}$ mencirikan komposisi logam dari sedimen sungai tailing tambang dan sedimen laut di Buyat dan Ratatotok. Hal ini dikonfirmasikan kembali dalam laporan yang dilakukan oleh tim terpadu Kementerian Lingkungan Hidup ${ }^{5}$ yang menyebutkan bahwa penambangan liar menghasilkan limbah proses amalgamasi telah dibuang ke anak sungai di hulu Sungai Ratatotok. Penelitian yang dilakukan oleh Ilahude dan Herawati $^{3}$ pada tahun 2010 menemukan bahwa kadar arsen tertinggi pada enam titik sampel di Teluk Buyat dan Ratatotok terdapat di daerah pesisir pantai Ratatotok (127,8 ppm) yang diasosiasikan dengan akumulasi limbah arsenik berasal dari muara sungai Ratatotok yang kadarnya berkisar antara 4-130 ppm. Hal menunjukkan bahwa pembuangan limbah melalui sungai ke laut yang disebabkan oleh penambangan ilegal telah berkontribusi mencemari Teluk Totok. ${ }^{6,7}$

Arsen merupakan polutan bagi lingkungan sehingga diperlukan suatu agen untuk proses remediasi. ${ }^{1,2,8}$ Bakteri resisten arsen menjadi target dari banyak penelitian dalam rangka pemanfaatannya sebagai agen bioremediasi. ${ }^{8,10,11}$ Setiap bakteri resisten arsen memiliki gen operon yang berbeda untuk melakukan detoksifikasi. Struktur gen operon ars umumnya terdiri dari gen arsenat reduktase (arsC), gen pengkode pompa efluks arsenit (arsB dan $\operatorname{ars} \mathrm{A})$, gen regulator transkripsi (arsR), dan gen transpor arsenit (arsD). ${ }^{8,9}$ Berbagai penelitian telah mengidentifikasi bakteri resisten arsen dari air, tanah, dan daging ternak. Jenis-jenis bakteri yang ditemukan di antaranya Klebsiella pneumoniae, Enterobacter sp., Bacillus sp., Aneurinibacillus aneurinilyticus, Enterobacter asburiae, Enterobacter cloacae dan Campylobacter spp. ${ }^{10-13}$

Penelitian ini bertujuan untuk mengetahui jenis bakteri resisten arsen yang teridentifikasi pada sedimen tanah di pesisir pantai Ratatotok.

\section{METODE PENELITIAN}

Jenis penelitian yang digunakan yaitu dekriptif eksploratif. Penelitian dilakukan pada bulan September-November 2018 dimulai dengan pengambilan sampel di pesisir Pantai Ratatotok, sampai proses identifikasi di Laboratorium Mikrobiologi Farmasi FMIPA Universitas Sam Ratulangi. Populasi penelitian ini yaitu bakteri yang diambil dari sedimen tanah di pesisir pantai Ratatotok. Sampel penelitian yang digunakan yaitu koloni bakteri resisten arsen. Variabel penelitian ini yaitu jenis bakteri resisten arsen pada sedimen tanah di Pesisir Pantai Ratatotok yang diidentifikasi melalui metode identifikasi bakteri sederhana.

Prosedur kerja dimulai dengan penambilan sampel, yaitu sedimen tanah pesisir Pantai Ratatotok yang diambil pada kedalaman satu meter dari permukaan. Sampel kemudian dibawa ke Laboratorium Mikrobiologi Farmasi FMIPA Unsrat dan dilakukan isolasi pada media Luria Bertani (LB) agar dengan konsentrasi arsen trioksida $\left(\mathrm{As}_{2} \mathrm{O}_{3}\right)$ masing-masing 5 ppm 10 ppm, 20 ppm, 40 ppm, 80 ppm, 100 ppm, 300 ppm, 500 ppm, dan 1000 ppm. Koloni bakteri yang tumbuh kemudian dilakukan uji identifikasi secara morfologi, fisiologi, dan biokimia.. Hasil yang diperoleh kemudian ditabulasi dan dibandingkan dengan data pada buku Bergey's Manual Determinative of Microbiology.

\section{HASIL PENELITIAN}

Pada proses pemilihan isolat bakteri, dipilih koloni berdasarkan bentuk dan luas 
permukaan yang tampak pada media LB agar. Setelah diberi tanda, koloni tersebut digoreskan pada media LB agar di cawan Petri secara terpisah satu sama lain kemudian diberi label sesuai dengan jenis sampel dan konsentrasi

Terdapat pertumbuhan koloni bakteri pada cawan Petri di setiap konsentrasi yang semakin berkurang seiring dengan peningkatan konsentrasi arsen yang terkandung dalam media. Koloni yang terbentuk pada media LB agar tersebut diinokulasikan pada media agar miring masing-masing. Isolat yang terbentuk pada media agar selanjutnya diidentifikasi melalui uji fisiologi, uji biolomia, dan uji morfologi.

Hasil yang didapatkan pada uji morfologi dalam pewarnaan Gram. Isolat dengan kode RL K, RL 5, RL 10 ialah bakteri bentuk kokus Gram positif; isolat dengan kode RL 20, RL 40, RL 100, RL 300, RL 1000 ialah bakteri bentuk basil Gram negatif; sedangkan isolat dengan kode RL 80 dan RL 500 ialah bakteri bentuk kokus Gram negatif.

Tabel 1. Hasil pengamatan pewarnaan Gram

\begin{tabular}{clcc}
\hline No. & $\begin{array}{l}\text { Kode } \\
\text { isolat }\end{array}$ & $\begin{array}{c}\text { Bentuk } \\
\text { bakteri }\end{array}$ & Gram \\
\hline 1. & RL K & Kokus & Positif \\
2. & RL 5 & Kokus & Positif \\
3. & RL 10 & Kokus & Positif \\
4. & RL 20 & Basil & Negatif \\
5. & RL 40 & Basil & Negatif \\
6. & RL 80 & Kokus & Negatif \\
7. & RL 100 & Basil & Negatif \\
8. & RL 300 & Basil & Negatif \\
9. & RL 500 & Kokus & Negatif \\
10. & RL 1000 & Basil & Negatif \\
\hline
\end{tabular}

Pada hasil pengujian 10 isolat pada media nutrien agar tegak didapatkan bahwa semua isolat negatif, yakni pada media tidak ada pertumbuhan bakteri yang menyebar di sekitar tempat penusukan.

Hasil uji biokimia terdiri dari interpretasi hasil dari ketujuh uji. Uji fermentasi karbohidrat pada sampel dilakukan bersamaan dengan uji $\mathrm{H}_{2} \mathrm{~S}$. Uji ini dilakukan pada media TSIA (Triple Sugar Iron Agar), dan mendapatkan pada hasil semua isolat terjadi perubahan warna menjadi kuning di bagian dasar (butt), dan tetap berwarna merah pada bagian permukaan (slant) disertai pembentukan gas $\left(\mathrm{CO}_{2}\right)$. Hal ini berarti bahwa pada sampel hanya terjadi fermentasi glukosa tanpa disertai fermentasi laktosa dan sukrosa.

Uji $\mathrm{H}_{2} \mathrm{~S}$ menggunakan media TSIA (Triple Sugar Iron Agar) dan hasil positif didapatkan pada isolat dengan kode RL K, RL 5, RL 10, dan RL 20, yakni pada media terlihat adanya endapan berwarna hitam yang menandakan bahwa bakteri tersebut dapat membentuk $\mathrm{H}_{2} \mathrm{~S}$.

Uji indol mengunakan media nutrien agar yang diberi lima tetes reagen Kovac's, kemudian didiamkan sebentar. Pada uji indol didapatkan hasil positif pada isolat dengan kode RL 80, RL 100, RL 300, RL 500, dan RL 1000, yakni terlihat adanya pembentukan cincin merah pada permukaan media.

Uji sitrat dilakukan dengan menggunakan media Simmon's citrate agar. Semua isolat menunjukkan hasil positif yakni terjadi perubahan warna media dari hijau menjadi biru.

Uji lisin dekarboksilase menggunakan media Lysin iron agar. Semua isolat memberikan hasil positif, berupa adanya gumpalan berwarna lembayung (keunguan) yang menunjukkan bahwa bakteri dapat melakukan dekarboksilasi dalam asam amino berupa lisin melalui produksi enzim dekarboksilase.

Uji katalase menggunakan media nutrien agar yang ditetesi larutan peroksida $\left(\mathrm{H}_{2} \mathrm{O}_{2}\right)$. Hasil positif ditunjukkan dengan munculnya busa/gas yang merambat cepat keluar dari tabung. Semua isolat menunjukkan hasil positif. Hal ini menunjukkan bahwa bakteri pada isolat memiliki enzim katalase yang dapat memecah $\mathrm{H}_{2} \mathrm{O}_{2}$ menjadi $\mathrm{H}_{2} \mathrm{O}$ dan $\mathrm{O}_{2}$.

Bakteri yang telah dilakukan uji morfologi, biokimia, dan fisiologi tersebut kemudian diidentifikasi berdasarkan hasil yang didapat secara keseluruhan untuk menentukan genus bakteri yang terkandung dalam isolat. Mekanisme penentuan genus bakteri dilakukan dengan cara memban- 
dingkan uji yang didapat dalam penelitian dengan Bergey's Manual of Determinative Bacgteriology.

Isolat RL K, RL 5, dan RL 10 pada uji morfologi menunjukkan hasil kokus Gram positif. Berdasarkan bentuk dan jenis Gramnya maka bakteri dapat dikelompokkan dalam genus Staphylococcus. Bakteri pada genus ini memiliki uji fisiologi sel nonmotil dan uji katalase positif.

Isolat RL 20, RL 100, RL 300, dan RL 1000 menunjukkan hasil basil Gram negatif. Berdasarkan bentuk dan pewarnaan Gramnya, dikelompokkan dalam genus Klebsiella. Bakteri pada genus ini berbentuk basil Gram negatif dengan hasil uji fisiologi nonmotil sedangkan uji fermentasi karbohidrat memiliki hasil bervariasi namun cenderung positif.

Isolat RL 40 menunjukkan hasil basil Gram negatif sehingga dapat dikelompokan dalam genus Hafnia. Hal ini juga ditunjang dengan hasil uji yang ada dimana uji indol, $\mathrm{H}_{2} \mathrm{~S}$, dan fermentasi karbohidrat menunjukkan hasil negatif, dan uji katalase menunjukkan hasil positif.

Isolat RL 80 dan RL 500 pada uji morfologi menunjukkan hasil kokus Gram negatif. Berdasarkan bentuk dan pewarnaan gramnya, maka bakteri dikelompokkan dalam genus Acetobacter. Hal ini juga ditunjang dengan hasil uji fisiologi nonmotil, uji $\mathrm{H}_{2} \mathrm{~S}$ menunjukkan hasil negatif, dan hasil positif pada uji indol, lisin, sitrat, dan katalase.

\section{BAHASAN}

Bakteri merupakan organisme yang termasuk salah satu dari dua divisi besar dalam sistem tiga domain dan tergolong kelompok prokariotik (tidak mempunyai selubung inti). Bakteri terdiri dari sejumlah besar unisel yang biasanya berkembang biak dengan pembelahan sel (fisi) yang selnya biasanya berada di dalam dinding sel. Bakteri hidup bebas di alam dan beberapa bakteri tertentu dapat hidup dalam keadaan lingkungan ekstrim. ${ }^{14,15}$

Penelitian yang dilakukan pada sampel sedimen tanah di pesisir pantai Ratatotok melalui uji resistensi arsen mendapatkan temuan bakteri resisten arsen. Semua isolat yang diambil dari sampel tumbuh pada pemberian $\mathrm{As}_{2} \mathrm{O}_{3}$ konsentrasi 5 ppm, 10 ppm, 20 ppm, 40 ppm, 80 ppm, 100 ppm, 300 ppm, 500 ppm, dan 1000 ppm yang kemudian diinkubasi pada suhu $37^{\circ} \mathrm{C}$ selama 18-24 jam.

Kemampuan bakteri untuk bertahan hidup dalam lingkungan yang mengandung arsen dikarenakan bakteri resisten arsen memiliki gen yang mampu melakukan oksidasi, reduksi, dan metilasi arsen, yaitu gen operon ars. Setiap bakteri resisten arsen memiliki gen operon yang berbeda untuk melakukan detoksifikasi. Struktur gen operon ars umumnya terdiri dari gen arsenat reduktase (arsC), gen pengkode pompa efflux arsenit (arsB dan ars $\mathrm{A})$, gen regulator transkripsi (arsR), dan gen transpor arsenit (arsD). ${ }^{8,9}$

Staphylococcus sp. merupakan bakteri kokus gram positif yang bergerombol seperti anggur. Bakteri yang bersifat nonmotil ini dapat tumbuh dalam keadaan anaerob dengan fermentasi karbohidrat tetapi dapat tumbuh lebih bagus secara aerob. Uji katalase menunjukkan hasil positif. Mikroorganisme ini dapat ditemukan di kulit, nasal, dan membran mukosa lainnya. Bakteri ini memroduksi berbagai variasi toksin, dapat berpotensi patogenik, dan menyebabkan keracunan makanan. Pada kulit, dapat menyebabkan supurasi dan pembentukan abses, berbagai infeksi piogenik hingga septikemia yang fatal. Staphylococcus dapat dengan cepat menjadi resisten terhadap agen-agen anti mikroba sehingga dapat menimbulkan kesulitan dalam pemberian terapi. ${ }^{15,16}$

Klebsiella sp. merupakan bakteri fakultatif anaerob Gram negatif yang bersifat nonmotil. Sel berbentuk batang lurus berkapsul dengan diameter 0,3-1,0 $\mu \mathrm{m}$ dan panjang 0,6-6,0 $\mu \mathrm{m}$ yang dapat tersusun secara tunggal, ganda, atau dalam bentuk rantai pendek. Bakteri ini dapat tumbuh secara optimal dalam suhu $37^{\circ} \mathrm{C}$ dan mampu mengkatabolisme glukosa dan karbohidrat lain disertai produksi asam dan gas. Uji indol dan sitrat menghasilkan reaksi yang bervariasi antar spesies. 
Bakteri pada genus ini terdapat pada feses manusia, tanah, air, biji-bijian, buah, dan sayuran. Mikroorganisme ini dapat menyebabkan bakteremia, pneumonia, infeksi traktus urinaria dan infeksi lain pada manusia. Bakteri ini sering menyebabkan infeksi nosokomial pada pasien urologi, neonatus, perawatan intensif, dan geriatri. ${ }^{16}$

Hafnia sp. merupakan genus bakteri Gram negatif berbentuk basil lurus dengan diameter sekitar $1 \mu \mathrm{m}$ dan hidup pada suhu 30-37 ${ }^{\circ} \mathrm{C}$. Bakteri ini mampu memroduksi glukosa disertai pembentukan gas. Genus ini hanya memiliki satu spesies heterogen, yaitu Hafnia alvei. Mikroorganisme ini terdapat pada manusia, hewan, tanah, air, dan produk susu dan bersifat patogen oportunistik pada manusia, biasanya dalam darah, urin, gastroenteritis, atau infeksi luka pada pasien dengan penyakit pendahulu atau faktor predisposisi. ${ }^{15,16}$

Acetobacter sp. merupakan genus bakteri Gram negatif yang dapat bersifat motil maupun nonmotil tergantung spesies bakterinya. Bakteri ini bersifat obligat aerobik, metabolisme secara respirasi dan tidak pernah secara fermentasi. Uji katalase menunjukkan hasil positif. Tumbuh optimal pada suhu $25-30^{\circ} \mathrm{C}$ dan $\mathrm{pH}$ 5,4-6,3. Mikroorganisme ini terdapat pada bunga, buah, madu, produk hasil fermentasi, cuka, tanah perkebunan, dan air kanal. Beberapa acetobacter menyebabkan penyakit pink pada buah nanas dan batang apel. ${ }^{15,16}$

\section{SIMPULAN}

Berdasarkan hasil penelitian ini dapat disimpulkan bahwa terdapat empat genus bakteri resisten arsen yaitu Staphylococcus, Klebsiella, Hafnia, dan Acetobacter pada sampel sedimen tanah pesisir pantai Ratatotok yang diidentifikasi melalui uji morfologi, uji fisiologi, dan uji biokimia.

\section{DAFTAR PUSTAKA}

1. Agency for Toxic Substances and Disease Registry (ATSDR). Toxicological profile of arsenic. Atlanta: U.S. Department of Health and Human Services, 2007.

2. Garelick H, Jones H, Dybowska A, Valsami-
Jones E. Arsenic pollution sources. Rev Environ Contam Toxicol. 2008: 197:17-60.

3. Ilahude D, Herawati E. Heavy metal contents in marine sediments and seawater at Totok bay area, North Sulawesi. BuMG. 2010:25:39-51.

4. Edinger EN, Blackwood GM, Raja P. Heavy metal concentrations in shallow marine sediments affected by submarine tailings disposal and artisanal gold mining, Buyat-Ratototok district, North Sulawesi, Indonesia. Environmental Geology. 2007:52:701-14.

5. Kementerian Lingkungan Hidup. Laporan penelitian penanganan dugaan kasus pencemaran dan/atau perusakan lingkungan hidup di Desa Buyat Pantai dan Desa Ratatotok Kecamatan Rata-totok Timur Kabupaten Minahasa Selatan Provinsi Sulawesi Utara [serial online] 2004. Available from: http://menlh. go.id/terbaru/artikel.php/ article_id1151.

6. Lahar H. Evaluasi sumber daya dan cadangan bahan galian untuk pertambangan skala kecil daerah lembar Manado, Provinsi Sulawesi Utara. Kolokium Hasil Lapangan DIM. 2004;45:1-12.

7. Rumampuk NDC, Warouw V. Bioakumulasi total merkuri, arsen, kromium, cadmium, timbal di Teluk Totok dan Teluk Buyat, Sulawesi Utara. Jurnal LPPM Bidang Sains dan Teknologi. 2015:2;49-59.

8. Satyapal GK, Rani S, Kumar M, Kumar N. Potential role of arsenic resistant bacteria in bioremediation: Current status and future prospects. J Microb Biochem Technol. 2016;8:256-8.

9. Kruger MC, Bertin PN, Heipieper HJ, Arsène-Ploetze F. Bacterial metabolism of environmental arsenic-mechanisms and biotechnological applications. Appl Microbiol Biotechnol. 2013;97:3827-41.

10. Abbas SZ, Mehwizh Riaz, Rafatullah M. Isolation and identification of arsenic resistant bacteria from wastewater. Brazilian Journal of Microbiology. 2014:45:1309-15.

11. Dey U, Chatterjee S, Mondal NK. Isolation and characterization of arsenic resistant bacteria and possible application in bioremediation. Biotechnology Re- 
ports. 2016;10:1-7.

12. Selvi MS, Sundaresan S, Sivasamy G, Pillai RP, Sasikumaar P, Sadasivam SG. Isolation and characterization of arsenic resistant bacteria from agricultural soil, and their potential for arsenic bioremediation. International Journal of Agricultural Policy and Research. 2014;2(11):393-405.

13. Sapkota AR, Price LB, Silbergeld EK, Schwab KJ. Arsenic resistance in campylobacter spp. isolated from retail poultry products. Appl Environ Microbiol. 2006;72(4):3069-71.
14. Dorland WAN. Kamus kedokteran Dorland (31st ed). Jakarta: EGC, 2010; p. 191.

15. Brooks GF, Carrol KC, Butel JS, Morse SA, Mietzner TA, Jawetz, Melnick. Medical Microbiology. In: Adiyaputri A, penyunting. Jawetz, Melnick, Adelberg. Mikrobiologi Kedokteran (25 th ed). Jakarta: EGC, 2010.

16. Holt JG, Krieg NR, Sneath PHA, Staley JT, Williams ST. Bergey's Manual of Determinative Bacteriology (9th ed) United States; The Williams and Wilkins Company, 1994; p. 71-532. 